\title{
PENGABDIAN MASYARAKAT DENGAN TEMA PELATIHAN PEMASARAN ONLINE PADA KARANG TARUNA KALURAHAN MANAHAN KECAMATAN BANJARSARI KOTA SURAKARTA
}

\author{
Rahayu Triastity ${ }^{1)}$ \\ Rina Susanti ${ }^{2}$ \\ 1,2) Dosen Fakultas Ekonomi Universitas Slamet Riyadi Surakarta \\ 1) iburahayusolo@gmail.com \\ 2) my.rinasusanti@gmail.com
}

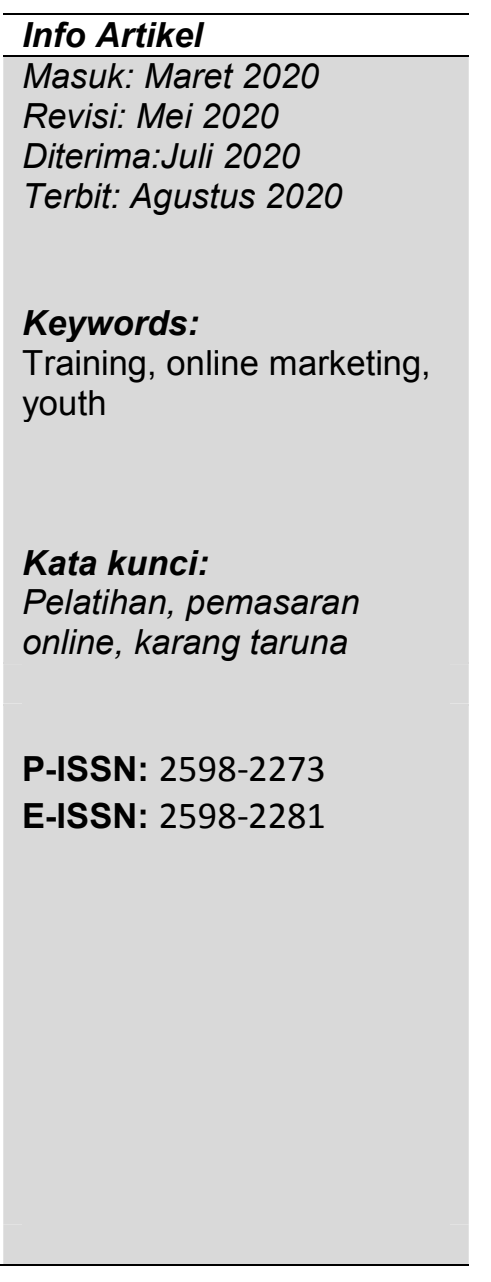

\begin{abstract}
The Community Service Program (PPKM) aims to ensure that members of the Youth Organization have entrepreneurial management skills so that there is business continuity, which in turn can increase the income of the target audience for community service activities in the community of Youth in the Manahan Village, Banjarsari District, Surakarta City. Counseling methods include lectures, discussions, questions and answers. The extension activity plan was held once, in the form of online marketing training.

The output of this activity is Karang Taruna has online marketing skills. The transfer of science and technology that is held aims to make Karang Taruna have online marketing skills and enter proceedings.
\end{abstract}

\begin{abstract}
Abstrak
Program Pengabdian Kepada Masyarakat (PPKM) ini bertujuan agar supaya anggota karang taruna memiliki kemampuan manajemen wirausaha sehingga ada kelangsungan usaha, yang pada akhirnya bisa meningkatkan pendapatan khalayak sasaran kegiatan pengabdian kepada masyarakat ini adalah karang taruna di Kelurahan Manahan Kecamatan Banjarsari Kota Surakarta. Metode penyuluhan antara lain ceramah, diskusi, tanya jawab. Rencana kegiatan penyuluhan dilakukan satu kali pertemuan, berupa pelatihan pemasaran online.

Luaran dari kegiatan ini adalah Karang taruna mempunyai ketrampilan pemasaran online Transfer iptek yang diselenggarakan ini bertujuan agar karang taruna memiliki ketrampilan pemasaran online dan masuk proceeding.
\end{abstract}

\section{PENDAHULUAN}

Pemasaran adalah suatu proses sosial dan manajerial yang didalamnya individu dan kelompok untuk mendapatkan apa yang mereka butuhkan dan inginkan dengan menciptakan, menawarkan, dan mempertukarkan produk yang bernilai kepada pihak lain (Kotler, 1997). Definisi pemasaran ini bersandar pada konsep inti yang meliputi kebutuhan (needs), keinginan (wants), dan permintaan (demands).

Dan menurut William J. Stanton dalam Basu Swasta (1998:179) pemasaran adalah suatu sistem keseluruhan dari kegiatan usaha yang ditujukan untuk 
merencanakan, menentukan harga, mempromosikan, dan mendistribusikan barang dan jasa untuk memuaskan kebutuhan kepada pembeli yang ada maupun pembeli potensial. Pengertian tersebut dapat memberikan gambaran bahwa pemasaran merupakan proses pertemuan antara individu dan kelompok dimana masing- masing pihak ingin mendapatkan apa yang mereka butuhkan atau inginkan melalui proses menciptakan, menawarkan, dan pertukaran. Selain itu, pemasaran sebagai suatu sistem dari kegiatan yang saling berhubungan satu dan yang lainnya, yang ditujukan untuk merencanakan, menentukan harga, mempromosi- kan, dan mendistribusikan barang atau jasa kepada pembeli secara individual maupun kelompok pembeli. Kegiatan tersebut beroperasi dalam suatu lingkungan yang dibatasi sumber dari perusahaan, peraturan-peraturan, maupun konsekuensi sosial perusahaan.

Berdasarkan hubungan antara penjual atau pemasar dengan pembeli maka pemasaran dapat dibedakan menjadi pemasaran langsung (of line) dan pemasaran tidak langsung yaitu pemasaran menggunakan media internet (on line). Yang dimaksud pemasaran langsung yaitu pemasar (penjual) berkomunikasi langsung dengan pelanggan individu yang dibidik secara seksama baik untuk memperoleh tanggapan segera maupun membina hubungan pelanggan yang berlangsung lama, model pemasaran ini sering disebut dengan model bisnis yang langsung ke pelanggan (direct-to-customers bussines model). Sedangkan yang dimaksud dengan pemasaran tidak langsung atau pemasaran menggunakan media internet (Internet Marketing) yang sering disebut dengan pemasaran on line (marketing on line) merupakan kegiatan komunikasi pemasaran dengan menggunakan media Internet.

Sekarang ini, untuk memasarkan barangyang akan dijual kepada pembeli tidak perlu menjualkan barangnya langsung kepada pembeli. Dengan pemasaran onlineyang memanfaatkan teknologi search enginedapat mengundang calon pelanggan yang relevan dengan produk/jasa yang di tawarkan untuk mengetahui produk/jasa melalui website. Karena saat ini banyak orang yang mencari barang di internet maka hanya perlu menjelaskan barang yang di jual secara detail.

Sebuah penelitian menyimpulkan bahwa media sosial telah meningkatkan kinerja dari bisnis dan 90 persen responden menganggap social media penting untuk bisnis mereka. Manfaat utama yang diperoleh dari social media adalah brand 
awareness.Dari penelitian tersebut, manfaat lain yang diperoleh responden dari social media bagi UKM adalah:

- Meningkatkan Traffic - 72 persen

- Peningkatan Pencarian Peringkat - 62 persen

- Kemitraan Baru - 59 persen

- Peningkatan Penjualan - 48 persen

- Pengurangan Biaya Pemasaran - 59 persen untuk wiraswasta, 58 persen untuk UKM

- Dua kali lebih mungkin untuk menemukan prospek yang berkualitas

Melalui media sosial dan alat seperti Twitter, Facebook dan blogging dia mampu menjangkau dan membangun kesadaran tidak seperti sebelumnya.

Selanjutnya, di bawah ini akan dibahas materi yang terkait dengan pemasaran online, yaitu meliputi pengertian pemasaran online, konsumen online, cara melakukan pemasaran on line,strategi pemasaran internet, peluang dan tantangan pemasaran online, pelayanan (service) pemasaran online, strategi promosi (promotion strategy), dan menjaga hubungan baik (maintaining relationships).

\section{METODE PELAKSANAAN}

Metode penyuluhan antara lain ceramah, diskusi, tanya jawab. Rencana kegiatan penyuluhan dilakukan satu kali pertemuan, berupa pelatihan pemasaran online.

\section{PEMBAHASAN}

\section{Pengertian Pemasaran Online}

Pemasaran Online (Online Marketing)merupakan kegiatan komunikasi pemasaran dengan menggunakan media Internet. Pada awalnya menggunakan halaman-halaman statis berformat HTML (HyperText Markup Language) yang bisa diakses oleh pengguna Internet. Itulah awal dari website yang kemudian menjadi semacam 'brosur online' dan bahkan 'kantor kedua' bagi perusahaan-perusahaan untuk menampilkan jati dirinya ke seluruh dunia. Pemasaran online dilakukan melalui 
sistem komputer online interaktif, yang menghubungkan pembeli dan penjual secara elektronik.

Ada2 (dua ) jenis saluran pemasaran online:

a. Layanan Online Komersial, Internet layanan yang menawarkan informasi dan layanan pemasaran online kepada pelanggan yang membayar biaya bulanan, seperti America online, Compuserve dan Prodigy.

b. Internet, Web global jaringan komputer yang luas dan berkembang pesat yang tidak mempunyai manajemen dan kepemilikan sentral.

Pertumbuhan pemasaran online berkembang menjadi perdagangan elektronik (E-Commerce).Perdagangan elektronik (E-Commerce) merupakan istilah umum untuk proses pembelian dan penjualan yang di dukung oleh sarana elektronik.

\section{Manfaat Pemasaran Online}

\section{a. Murah dan efisien}

Untuk dapat membuka toko secara fisik akan membutuhkan modal jutaan rupiah, hal ini berbeda dengan modal yang diperlukan untuk membuat toko online hanya ratusan ribu rupiah, bahkan saat ini sudah banyak fasilitas di internet yang dapat kita manfaatkan untuk membuka toko online dengan gratis. Selain itu biaya operasional toko online hanya pada biaya akses internet tanpa perlu karyawan.

b. Pemasaran online melalui internet tidak terbatas oleh waktu, tidak seperti bisnis offline lainnya. Layanan pemasaran bisnis melalui internet bisa diakses konsumen kapan saja selama ada jaringan internet.

c. Pemasaran online melalui internet juga menjangkau pasar lebih luas. Melalui bisnis internet, produkdapat diinformasikan hingga ke seluruh daerah di nusantara, bahkan menjangkau pasar luar negeri.

d. Dengan memakai strategi pemasaran online melalui internet. Dapat meningkatkan image perusahaan dimata para konsumen, sehingga memberikan nilai lebih untuk menghadapi persaingan bisnis yang ada. 
e. Mengurangi biaya pemasaran, karena pemasaran online melalui internet lebih tertarget dan biayanya relatif lebih rendah dibandingkan biaya pemasaran offline yang biayanya lebih besar untuk membuat brosur, spanduk, banner, neon box, dll.

\section{f. Memudahkan pelaku usaha untuk menjalin hubungan dengan para} konsumen. Karena melalui internat dapat terjalin komunikasi yang interaktif antara konsumen dengan pelaku bisnis, misalnya saja melalui kotak saran atau ruang komentar, serta forum diskusi antar konsumen. Sehingga bila komunikasi terjaga dengan baik, loyalitas konsumen juga dapat meningkat.

Walaupun pemasaran online memiliki banyak keuntungan seperti yang telah disebutkan diatas, pemasaran online juga memiliki kekurangan, yaitu:

a. Mengharuskan pelanggan untuk menggunakan teknologi internet.

b. Rendahnya kecepatan koneksi internet juga dapat menjadi hambatan

c. Konsumen di internet tidak dapat menyentuh, mencium, merasakan atau mencoba barang secara nyata sebelum melakukan pembelian.

d. Adanya penipuan dalam penjualan secara online

\section{Konsumen online}

Konsumen online adalah penguna internet. Berbagai macam Situs Social Network (Jejaring Sosial) yang tumbuh berkembang seperti Friendster, Facebook, MySpace, Twitter, Nexopia, Orkut, dol2day, dan lain-lain. Situs-situs Social Network (Jejaring Sosial) tersebut mempunyai jutaan member dan visitor. Sebagai gambaran mengenai berapa jumlah pengunjung pada situs Social Network (Jejaring Sosial) yang tumbuh berkembang pada saat ini, maka berdasarkan sumber comScore Media Metrix, di Asia Friendster memiliki lebih dari 32 juta unique visitor, MySpace.com memiliki lebih dari 15 juta unique visitor, dan Facebook memiliki lebih dari 14 juta unique visitor per bulannya. Pada Facebook, pada tahun 2007, terdapat penambahan 200 ribu account baru perharinya. Lebih dari 25 juta user aktif 
menggunakan Facebook setiap harinya. Rata-rata user menghabiskan waktu sekitar 19 menit perhari untuk melakukan berbagai aktifitas di Facebook.

Begitu besarnya jumlah member dan visitor yang terdapat pada Situs Social Network (Jejaring Sosial) dapat dilihat sebagai potensi pasar yang dapat dimanfaatkan sebagai media atau sarana pemasaran

\section{Cara melakukan pemasaran online dengan:}

\section{a. Menciptakan kehadiran online elektronik}

Cara ini bisa dilakukan dengan dua cara yaitu (1) Membeli ruang dilayanan online komersial. (2) Membentuk situs internet sendiri misalnya dengan Situs Internet Perusahaan (corporate Web Site), Situs Internet Pemasaran (marketing Web Site).

b. Menempatkan Iklan Online, merupakan iklan yang muncul ketika para pelanggan menjelajahi layanan online/situs internet yang mempunyai papan iklan, jendela timbul tengelam, ticker, roadblock.

\section{Strategi Pemasaran Internet}

Strategi Pemasaran Internet adalah proses penyusunan komunikasi terpadu yang bertujuan untuk memberikan informasi mengenai produk barang atau jasa dalam kaitannya untuk memuaskan kebutuhan dan keinginan manusia melalui media internet.

Secara garis besar strategi pemasaran online dapat dibagi menjadi 6 langkah, yang bisa disingkat menjadi SISTEM :

a. S - Search and research. Melakukan proses pencarian dan riset ceruk pasar dan kompetitor yang ada.

b. I - Initiate strategy. Tentukan sistem dan strategi yang akan dipergunakan untuk menjangkau prospek dan pelanggan.

c. S - Start content engine. Pergunakan berbagai konten untuk menarik orang kepada bisnis yang ditawarkan.

d. $T$ - Traffic. Mendatangkan pengunjung ke situs bisnis yang ditawarkan. 
e. E - Embrace relationship. Bina hubungan dengan pelanggan melalui berbagai kanal.

f. $\boldsymbol{M}$-Money. Strategi mendatangkan pendapatan dan keuntungan.

Berikut penjelasan langkah demi langkah termasuk beberapa sumber daya yang dapat dipergunakan bila ingin menggali lebih dalam.

\section{a. S - Search and Research}

Memiliki toko online tanpa mengerti untuk apa toko itu dipakai tidak akan banyak bermanfaat. Mengapa? Karena kompetitor segera akan menjadi lawan yang pelik dengan persaingan yang tinggi. Metode terbaik untuk sukses dalam suatu ceruk pasar adalah melakukan riset dengan harapan:

- Bisa menemukan prospek dan pembeli yang tertarik dengan produk maupun jasa yang di tawarkan.

- Dapat memberikan nilai tambah dalam bentuk pengetahuan maupun layanan.

- Dengan efisien dapat menjangkau pasar atau bekerjasama dengan pemain yang ada.

Banyak sekali cara seorang marketer dapat mendapatkan pelanggan dari dunia maya. Ada yang memilih memakai jalan pintas dengan membeli iklan di situs-situs yang ramai pengunjung atau dari mesin pencari. Cara yang mudah untuk mendapatkan pelanggan yaitu dengan membuka toko di Mall Online seperti Bursamuslim.com karena dengan membuka toko di Bursamuslim.com potensi pembeli yang berkunjung ke toko onlinelebih banyak dari pada membuka sebuah toko online sendiri.

\section{b. I - Initiate Strategy}

Situs web atau membuka toko online merupakan bagian terpenting dalam strategi pemasaran online. Banyak situs web yang menyediakan sarana buka toko yang gratis yang bisa di manfaatkan. Selain fitur gratis yang diberikan oleh penyedia web tentu biasanya ada juga fitur premium atau berbayar. Untuk memperoleh peluang lebih besar mendapatkan pengunjung atau calon pembeli produk barang atau jasa, bisa mencoba dengan bergabung dengan fitur premium tersebut, tentu banyak sekali keuntungan yang akan diperoleh dari pada menjadi reguler member 
karena akan mendapatkan prioritas-prioritas dari web penyedia Toko Online tersebut.

\section{S - Start Content Engine}

Konten masih merupakan materi penting dalam strategi pemasaran online. Mengapa? Karena semua orang ketika berselancar di dunia maya, mereka mencari konten dalam satu bentuk atau lainnya.

Strategi membuat konten tidak serumit yang dibayangkan kebanyakan orang. Dengan cara yang benar, juga dapat memenuhi situs dengan konten yang diinginkan pemirsa. Hal ini memungkinkan terjadinya penjualan tanpa harus menjual. Suatu konsep yang mungkin kontroversial karena pelanggan dan klien yang datang mencari, dan bukan sebaliknya. Strategi pemasaran Internet ini dinamakan content marketing. Penulisan judul dan deskripsi produk juga termasuk Content Marketing.

\section{d. $T$ - Traffic}

Beberapa strategi yang populer untuk meningkatkan traffic:

- Search Engine Optimization (SEO). Ilmu, teknik dan proses memposisikan halaman situs web di posisi yang tinggi di halaman pencarian untuk kata kunci yang dipakai prospek dan pelanggan.

- Pay per click(PPC) atau bayar/biaya per klik. Sistem periklanan yang diterapkan di Google salah satunya, di mana setiap kali iklan diklik, harus membayar sejumlah uang. Strategi ini bekerja dengan baik untuk eksperimen dan jika telah memiliki proses penjualan yang baik.

- Media Buying. Meliputi pembelian iklan untuk ditampilkan pada berbagai situs. Strategi ini dapat dikombinasikan sekaligus dengan teknik pemasaran di dunia nyata dalam bentuk pembelian iklan di radio, televisi dan media cetak.

- Social Media. Strategi ini naik daun pada beberapa tahun belakangan ini. Pada dasarnya ia meliputi interaksi langsung dengan pemirsa, prospek dan konsumen di situs media sosial. 
- Email Marketing. Mempergunakan email sebagai sarana komunikasi menjangkau pemirsa. Dengan konten yang baik akan dapat menarik pengunjung kembali ke situs berulang kali.

- Al-Amin Seller di Bursamuslim.com. Al-Amin Seller merupakan fitur premium seller(berbayar) di Bursamuslim.com. Dengan dana yang hemat, Anda ditawarkan posisi iklan dengan target yang tepat, yaitu di Halaman Depan Bursamuslim.com. Keuntungan tentang Al-Amin Seller bisa di lihat di http://blog.bursamuslim.com/al-amin-seller/

- Iklan Adpoint di Bursamuslim.com. Iklan Adpoint merupakan fitur iklan berbayar yang lebih hemat daripada Al Amin Seller. Anda bisa memilih jenis iklan adpoint seperti Hot Product, Sponsor Product, Hot Label, dan lain-lain. Ada banyak lagi strategi yang dapat disebutkan berupa kombinasi ataupun variasi dari apa yang disebutkan di atas.

\section{e. E-Embrace relationship}

Sebagaimana indahnya situs yang dibuat tidak akan mengubah kenyataan bahwa sebagian orang tidak akan membeli pada saat kunjungan pertama. Mungkin mereka beluma yakin. Prospek yang diharapkan mungkin ingin mencari informasi dari situs lain. Atau mereka masih dalam tahap perencanaan sehingga pilihan belum diputuskan.

Itulah sebabnya diperlukan suatu metode agar dapat merangkul dan menuntun mereka melalui suatu proses. Jika dapat membuktikan bahwa situs memahami apa yang mereka lalui, mendemonstrasikan bahwa situs sanggup membantu mereka atau memiliki tawaran terbaik yang mereka cari, maka pada saat mereka siap nantinya... dapat di tebak siapa yang mereka ingat. Dan tebak ke mana uang mereka akan mengalir?

Website tidak dapat melakukan semua tugas dengan baik. Oleh sebab itu dibutuhkan email sebagai sarana komunikasi. Ada sistem yang mengizinkan untuk mengumpulkan nama dan alamat email prospek dan mengirimkan mereka informasi-informasi dengan teratur. Jadi tidak perlu kuatir bila suatu saat akan memiliki seratus ribu bahkan sejuta orang dalam daftar prospek, semuanya dapat ditangani dengan sistematis. 
Alternatif sarana yang dapat digunakan untuk membangun hubungan dengan prospek adalah media sosial. Di Facebook, dapat berkomunikasi secara hampir real-time dengan mereka, berinteraksi, meminta pendapat, memberikan tips dan bahkan mengirimkan promosi dan informasi produk baru.Kedua teknik di atas sangat berbeda implementasinya, tapi inti pemakaiannya sama.

Bila belum yakin harus dengan strategi ini, ketahuilah bahwa biaya yang dikeluarkan untuk mendapatkan pelanggan baru sampai lima kali dari biaya untuk mendapatkan penjualan dari pelanggan yang telah ada. Pelanggan yang pernah membeli selalu akan mengingat selagi ada kesempatan, bila pengalaman yang diberikan baik.

Email dan media sosial adalah dua sarana ataupun kanal yang juga dapat di pergunakan untuk tujuan ini.

\section{f. M-Money}

Semua langkah di atas tujuannya adalah mendatangkan pendapatan yang menguntungkan. Semua proses di atas harus di lalui bila ingin sampai pada tahap ini. Uang tidak akan berpindah tangan kecuali dapat mencari pelanggan dan memberikan sesuatu yang bernilai sebagai gantinya.

Setelah memiliki pengunjung dan menghasilkan penjualan, salah satu langkah yang harus di lakukan adalah optimasi proses sehingga taraf konversi seseorang dari pengunjung ke prospek dan prospek ke pelanggan semakin tinggi. Jika awalnya dari 200 orang 1 membeli dan Anda meningkatkannya menjadi 1 pembeli setiap 100 orang, maka teorinya, keuntungan didapat berlipat ganda.

Jadi, sampai ke langkah ini bukan berarti akhir dari kesemuanya. Seperti halnya bisnis, semua merupakan proses yang terus dilakukan, dan berpotensi dikembangkan dan dimajukan.

\section{Peluang dan Tantangan Pemasaran Online}

Peluang Pemasaran online adalah menjadi model bisnis yang penuh dan lengkap dengan beberapa perusahaan.

Tantangan pemasaran online:

a. Keterpaparan dan pembelian konsumen yang terbatas. 
b. Demografis dan psikografis pengusaha menjadi menyimpang.

c. Kekacauan dan kesemrawutan.

d. Keamanan.

e. Kepedulian etis.

\section{Pelayanan (Service)}

Sebaik apapun barang dan sebaik apapun promosi jika tidak dapat memberikan pelayanan yang baik maka hanya dalam waktu singkat usaha akan mati, 4 hal utama yang harus diperhatikan dalam pelayanan yaitu:

a. Quick Response, harus melayani calon pelanggan dengan cepat, tentu sangat memakan biaya jika harus melayani calon pembeli satu persatu lewat telepon untuk itu di website diperlukan fasilitas chatting online dan contact form bagi mereka yang ingin mengetahui lebih lanjut atau berniat mau membeli produk.

b. Delivery Service, harus menggunakan layanan pengiriman yang terbaik dan terpercaya bagi para pembeli, jangan sampai barang yang kirim rusak apalagi hilang didalam perjalanan. Sekali mengecewakan calon pembeli, maka dengan sangat mudah mereka akan menyebarkannya lewat berbagai media online sehingga membuat nama bisnis jatuh.

c. Payment System, harus memberikan kemudahan bagi calon pembeli dalam melakukan pembayaran, tentunya dapat menggunakan berbagai fasilitas pembayaran yang ada seperti Pay Pal, dan lain-lain.

d. After Sales Service, memberikan layanan purna jual yang baik kepada para pelanggan. Tentunya jika produk yang mereka beli rusak, sudah seharusnya mau untuk memperbaiki ataupun mengganti produk tersebut. Sehingga mereka puas terhadap pelayanan yang diberikan, dan bagi mereka yang puas tentunya dapat meminta testimoni agar dapat memasangnya diwebsite, dengan adanya testimony akan meningkatkan kepercayaan bagi calon pembeli.

\section{Strategi Promosi (Promotion Strategy)}


Dalam pemasaran onlineharus menggunakan strategi pemasaran yang tepat dalam memasarkan produk, didalam pemasaran online ada $\mathbf{5}$ Strategy yang paling baik untuk dilakukan yaitu:

a. Web ...0, Sebuah website dapat menjual sesuatu jika memiliki pengunjung yang tinggi kita tahu bahwa sebuah website jika ingin memiliki traffic tinggi harus menggunakan sistem web 2.0 dimana disediakan fasilitas agar para pengunjung dapat melakukan interaksi didalam website kita.

b. Search Engine Optimization (SEO), Jika seseorang ingin mencari atau bahkan membeli sesuatu maka mereka akan mencarinya di mesin pencarian seperti Google, Yahoo, ataupun MSN, untuk itu kita harus mengoptimalkan website kita agar alamat website kita dapat menempati peringkat yang baik didalam mesin pencarian.

c. Social Media Optimization, dapat memanfaatkan Social Media yang ada di dunia online seperti: facebook, twitter, youtube untuk membangun sebuah komunitas yang bertemakan produk brand. Dengan demikian akan membuat produk dikenal di masyarakat online.

d. Affiliate Program, dapat memberikan sebuah hak bagi para pelanggan Anda untuk turut menjual produk kita dan mereka mendapatkan sebuah kode link dimana jika ada pembelian yang terjadi berasal dari link tersebut maka secara otomatis kita akan memberikan komisi kepada mereka tergantung kesepakatan kita dengan mereka.

e. PPC Campaign, PPC singkatan dari Pay Per Click artinya iklan yang dihitung biayanya per-klik. Hal ini dapat menentukan budget maksimal untuk bulanan PPC Campaign.

\section{Menjaga Hubungan Baik (Maintaining Relationships)}

Dalam pemasaran onlineharus dapat menjaga hubungan baik dengan pelanggan, sehingga mereka akan membeli kembali. Ada 4 cara untuk menjaga hubungan baik dengan mereka:

a. Member System, Bagi mereka yang telah membeli produk maka dapat memberikan mereka fasilitas sebagai member, dapat memberikan sebuah kartu member sebagai penghargaan bagi mereka dan sebuah Account 
Member dimana mereka dapat mengakses halaman khusus didalam website. Dimana kita memperlakukan mereka secara special dengan memberikan diskon khusus pada hari-hari special bagi mereka, misalnya: ulang tahun mereka, ulang tahun pernikahan, dan lain-lain.

b. Email Marketing/ Newsletter, dapat memaintain pelanggan dengan mengirimkan email secara berkala yang isinya mengenai sesuatu hal yang berguna misalnya pengetahuan tentang produk Anda ataupun informasi tips \& trik yang berhubungan dengan produk Anda.

c. Special Promo, harus mengadakan special promo dan sangat baik jika memanfaatkan momen yang sedang berlangsung misalnya: lebaran, natal, tahun baru , hari kasih sayang (valentine), hallowen dan lain-lain.

d. Reward Point, dapat memberikan point bagi setiap pembelian yang dilakukan pelanggan, dimana jika mereka mendapat point dalam jumlah tertentu mereka dapat tukarkan dengan hadiah.

\section{Kendala utama dalam memulai usaha bisnis online adalah:}

\section{a.Koneksi Internet}

Mungkin bagi yang tinggal di daerah kawasan perkotaan atau kota-kota besar koneksi internet bukanlah menjadi suatu kendala yang berarti, namun sebaliknya bagi yang tinggal di desa dimana jaringan Internet masih jauh di bawah standart.

b. Penguasaan Bahasa Asing

Ini merupakan kendala terbanyak dan paling umum dimiliki oleh para pemula bisnis online yaitu faktor penguasaan bahasa asing atau Inggris. Walaupun ada saja solusi untuk mengatasi masalah tersebut seperti bisnis paid review dengan memakai jasa penerjemah namun tetap saja tidak akan maksimal usaha yang dilakukan karena sifat ketergantungan secara terusmenerus tidak akan bisa menjamin totalitas hasil usaha akan terwujud secara maksimal.

\section{c. Kemampuan dan Tekad}

Tekad saja alias modal nekat serta kemauan hasrat tinggi tidaklah cukup untuk sukses dalam bisnis internet tanpa memiliki kemampuan atau salah satu 
keahlian dasar dari seluruh cakupan yang dibutuhkan sebagai penunjang dalam hal ini adalah hal-hal yang merupakan bagian dari faktor yang harus setidaknya sedikit terpenuhi sebagai kelengkapan atau materi modal skill di bisnis online.

Jadi kesimpulan untuk melakukan pemasaran produk secara online adalah memerlukan modal yang cukup, pengetahuan yang lebih tentang internet, dan juga waktu yang banyak. Memiliki bisnis online sangat membutuhkan waktu, kreatifitas, dan juga modal yang cukup. Sebagai pemula mungkin solusi terbaik sebelum terjun di dunia bisnis online ada baiknya melakukan pendekatan secara personal pada orang-orang/ bloggerl marketer. Bisnis online juga merupakan alternative meskipun terkadang bisnis ini mempunyai kendala tersendiri. Sebisa mungkin kita harus bisa mengatasi masalah yang muncul dalam memasarkan produk.

\section{HASIL YANG DICAPAI}

\section{A. Pelaksanaan Kegiatan}

Sesuai dengan permasalahan yang dihadapi oleh Karang Taruna Kalurahan Manahan Kecamatan Banjarsari Kota Surakarta permasalahan pemasaran secara online, maka Program Pengabdian Masyarakat ini dilakukan dalam bentuk Transfer Iptek yang dilakukan berupa penyuluhan melalui pembekalan maupun pengetahuan mengenai strategi pemasaran online.

Harapannya agar Karang Taruna Kalurahan Manahan Kecamatan Banjarsari Kota Surakarta yang diberi penyuluhan pemasaran secara online sehingga bisa melangsungkan usahanya yang pada akhirnya bisa meningkatkan pendapatannya.

Dipilihnya sasaran Karang Taruna Kalurahan Manahan Kecamatan Banjarsari Kota Surakarta, selain merupakan kelompok masyarakat yang rutinitas melakukan kegiatan usaha, juga memperoleh wawasan pengetahuan dari penyelenggaraan Program Pengabdian Masyarakat LP2M Universitas Slamet Riyadi Surakarta.

Adapun tahap pelaksanaan kegiatan ini terbagi menjadi 3 (tiga) tahap sebagai berikut:

1. Tahap persiapan terdiri dari:

a. Persiapan administrasi sesuai dengan kebutuhan penyuluhan 
b. Melakukan koordinasi dengan Ketua Karang Taruna Kalurahan Manahan Kecamatan Banjarsari Kota Surakarta.

c. Menyiapkan materi penyuluhan

d. Menyiapkan jadwal penyuluhan

2. Tahap pelaksanaan yang terdiri dari:

a. Melakukan penyuluhan bagaimana cara melakukan pemasaran secara online.

b. Diskusi mengenai bagaimana agar melakukan pemasaran secara online sehingga bisa melangsungkan usaha.

3. Tahap evaluasi yang terdiri dari:

a. Presentasi kesimpulan penyuluhan.

b. Refleksi terhadap hasil kegiatan penyuluhan pemasaran secara online.

\section{B. Tahap Evaluasi Program}

Untuk mengukur tingkat keberhasilan kegiatan yang telah dilakukan, maka akan dilakukan evaluasi 3 (tiga) kali, yaitu evaluasi proses, evaluasi akhir dan evaluasi tindak lanjut. Setelah diberi penyuluhan, Karang Taruna Kalurahan Manahan Kecamatan Banjarsari Kota Surakarta dapat memahami dengan jelas perlunya perlunya melakukan pemasaran secara online. Penyuluhan yang dilaksanakan bertujuan untuk menunjang pengetahuan, wawasan serta utamanya memahami cara melakukan pemasaran secara online.

Dalam pelaksanaan evaluasi program menunjukkan penyuluhan berjalan dengan baik. Hal ini dapat dilihat dari hasil diskusi dan evaluasi yang dilakukan oleh Tim Pengabdian Masyarakat. Dengan demikian sesuai dengan kriteria keberhasilan program, maka penyuluhan ini akan dinilai berhasil apabila mampu meningkatkan keterampilan Karang Taruna Kalurahan Manahan Kecamatan Banjarsari Kota Surakarta dalam melakukan pemasaran secara online

\section{Kendala dan Tindak Lanjut yang Harus Dilakukan}

Kendala pelaksanaan program ini adalah sulitnya mencapai kesepakatan mengenai waktu pelaksanaan, karena pada umumnya peserta punya kegiatan rutinitas seperti sekolah dan bekerja. Selain itu dalam pelaksanaan kegiatan 
sringkali juga bersamaan dengan acara yang lain sehingga waktu yang digunakan sangat terbatas.

Berkaitan dengan kendala tersebut di atas Tim Penlaksana masih mampu mengatasi dengan melakukan koordinasi secara intensif dengan Karang Taruna Kalurahan Manahan Kecamatan Banjarsari Kota Surakarta maupun penanggung jawab wilayah tersebut.

\section{RENCANA TAHAPAN BERIKUTNYA}

\section{A. Program Lanjutan yang Harus Dilakukan}

Program lanjutan yang diusulkan sebagai perpanjangan dari program tahun 2019 adalah melanjutkan memberikan penyuluhan manajemen wirausaha agar supaya meningkatkan keterampilan berwirausaha.

\section{B. Rencana Tahap Berikutnya}

Rencana tahapan berikutnya yang akan dilaksanakan dalam Program Pengabdian kepada Masyarakat pada Karang Taruna Kalurahan Manahan Kecamatan Banjarsari Kota Surakarta adalah pendampingan dan evaluasi yang meliputi:

1. Pendampingan mengenai tata cara melakukan manajemen wirausaha.

2. Evaluasi program untuk melihat seberapa jauh program itu bermanfaat bagi Karang Taruna Kalurahan Manahan Kecamatan Banjarsari Kota Surakarta.

\section{PENUTUP}

\section{A. Kesimpulan}

Kesimpulan yang dapat diperoleh dari pelaksanaan program pengabdian kepada masyarakat pada Karang Taruna Kalurahan Manahan Kecamatan Banjarsari Kota Surakarta adalah :

1. Tingkat partisipasi yang tinggi dari mitra program pengabdian kepada masyarakat memberikan dampak positif bagi pelaksanaan program, terlihat dari antusiasme peserta mengajukan berbagai pertanyaan dan diskusi yang berjalan lancar. 
2. Pelaksanaan program mampu menghasilkan luaran-luaran yang diharapkan oleh program pengabdian kepada masyarakat ini, diantaranya adalah :

a. Pengembangan wawasan pengetahuan mengenai pemasaran online pada Karang Taruna Kalurahan Manahan Kecamatan Banjarsari Kota Surakarta

b. Peningkatan pengetahuan manajemen pemasaran online, transfer Iptek bidang manajemen sumber daya manusia utamanya mengenai strategi pemasaran online yang diselenggarakan Tim Pengabdian bertjujuan untuk menunjang pengetahuan, wawasan meningkatkan jiwa/semangat bagi Karang Taruna Kalurahan Manahan Kecamatan Banjarsari Kota Surakarta. 


\section{B. Saran}

Berdasarkan transfer Iptek yang telah dilaksanakan pada Karang Taruna Kalurahan Manahan Kecamatan Banjarsari Kota Surakarta, ada beberapa saran yang perlu dipertimbangkan yaitu :

Bagi Karang Taruna Kalurahan Manahan Kecamatan Banjarsari Kota Surakarta permasalahan pemasaran secara online sebagai informan kunci penyebarluasan informasi, hendaknya mampu memberdayakan hasil pengetahuan dan ketrampilan yang diperoleh dari kegiatan P2M bagi masyarakat pentingnya pemasaran secara online bagi perkembangan usaha.

\section{DAFTAR PUSTAKA}

Dharmmesta, B.S. \& Handoko, H.(1982), Manajemen Pemasaran: Analisis Perilaku Konsumen. Yogyakarta: PBFE Universitas Gadjah Mada.

Ferrel, O.C, Hirt, G. \& Ferrel, L.(2008). Business: A Changing World. New York: McGraw-Hill Book Company.

Kotler, P.(1980), Marketing Management: Analysis, Planning, and Control. 4th Ed. London: Prentice-Hall, Inc.

Kotler, P. dan Amstrong, Dasar-dasar Pemasaran, jilid 2, edisi ke-9, Bab 17

Stanton, W.J.(1978), Fundamentals of Marketing, 5th Ed. Tokyo: Kogakusha, McGraw-Hill Book Company. 